\title{
Impact of Social Media Influencer Marketing on the Intention to Buy Online Through Attitude on Advertising and Brands
}

\author{
Windy Dwi Astuti, Renny Risqiani* \\ Magister Management Program, Post Graduate Studies \\ Trisakti University \\ Jakarta, Indonesia \\ *rennyrisqiani@gmail.com
}

\begin{abstract}
This research aims to study the impact of influencers through social media which is focused on Influencer's Credibility, Influencer's Attractiveness, Fit-Influencer-Product Level and Meaning Transfer on the intention to buy online through Consumer Attitudes towards Advertising and Consumer Attitudes towards Brands. The method used for data analysis is to use Structural Equation Modeling (SEM). The questionnaire was collected from two hundred and sixty-five consumers who had bought fashion products online. The results indicate that online purchase intention can be directly influenced by consumer attitudes towards brands and also consumer attitudes towards advertising, while social media influencer marketing has no direct effect on Online Purchase Intention. Companies can improve consumer attitudes towards advertising through Influencer Credibility, Influencer Attractiveness, and Meaning Transfer. Consumer attitudes towards brands can be done through increasing the credibility of influencer and also the attitude of consumers towards advertising.
\end{abstract}

Keywords-influencer credibility, influencer attractiveness, influencer-product degree of fit, meaning transfer, attitude towards the ad, attitude towards the brand, online purchase intention

\section{INTRODUCTION}

Social media has proven to be an interactive channel that allows marketers to increase the presentation of audio-visual products and services, by offering more attractive and more sophisticated forms of digital advertising than traditional mass media [1]. Based on Indonesian digital data in 2019, as many as $56 \%$ of Indonesia's population actively uses social media with the most widely used platforms are YouTube, WhatsApp, Facebook, and Instagram.

The researchers argue that advertising through social media has a more significant and effective role in building attitudes towards brands and can influence buying intentions compared to traditional advertising [2]. If advertising is considered a sales tool and not an information channel, consumers feel threatened and will turn to word of mouth as a credible source for their purchasing decisions [3]. The form of word of mouth that focuses on social media and done professionally, one of which is through an influencer [4].

Influencers are people who have great potential to influence others, in this case, the followers because of properties such as the frequency of influencer communication itself or personal persuasion [5]. Influencers are known for their expertise in consumer awareness move to switch to the products or services offered easily [3].

Social learning theory states that in promoting the product, the intention of the individual to make a purchase is strongly influenced by consumer attitudes and influences the effectiveness of social media followers (source credibility, source attractiveness, product compatibility, and transfer of meaning) [6]. Endorser credibility can influence consumer attitudes towards advertisements and attitudes toward products offered, then attitudes will affect the purchase intention [7] Empirical studies conducted by Tanjung and Hudransyah [8] suggest that influencers can attract consumers to watch advertisements, but consumers may not pay attention to the brands being promoted because they focus on the influencers. Although this strategy has good prospects, business people do not understand how to choose the right influencers to market their products and choose a target audience to start influencer marketing $[9,10]$.

\section{LITERATURE REVIEW}

The credibility of influencers is considered as an important factor that can influence consumer purchase intentions and attitudes towards advertising [8]. In other studies, also stated that Influencer's credibility can influence consumer attitudes towards advertising $[7,11,12]$. Hypotheses can be formulated:

H1b: influencer's credibility has a positive effect on consumer attitudes on advertising

Information presented by a credible source can influence the trust, opinions, attitudes, and behavior of consumers towards the brand [6]. Another study found that attitudes 
towards brands can be influenced by influencer's credibility [7, $13]$. attitude

H1c: influencer's credibility has a positive effect on brand Influencer attractiveness in advertising affects consumer attitudes toward advertising and buying interest is high [8]. Another study finds influencer's attractiveness has an influence on online purchase intention [14]. Another research also found the influencer attractiveness has an influence on online purchase intention [13]. Therefore, the hypothesis can be stated as follows:

$\mathrm{H} 2 \mathrm{a}$ : Influencer's attractiveness has a positive influence on consumers' intention to buy online.

Influencers with a good physical appearance and/or nonphysical character of interest can support advertising and can generate interest in the audience to listen to the ads [15]. Different studies found that attractiveness influencers have an influence on the attitude toward the ad $[13,16]$. Therefore, the following hypothesis has been developed:

$\mathrm{H} 2 \mathrm{~b}$ : The attractiveness of influencers has a positive effect on consumer attitudes towards advertising

Influencers can enhance the brand value of the product being advertised [15]. The attractiveness influencers have an influence on the attitude towards the brand [17]. Another study found that attractiveness influencers have an influence on brand attitude [13]. Therefore, the following hypothesis can be proposed:

$\mathrm{H} 2 \mathrm{c}$ : Influencer's attractiveness has a positive effect on consumer attitude on brands.

Influencer degree of fit-product is a model that shows that influencers should be appropriate in support of the product, the product uses can increase consumer interest towards such goods [18]. Another study also found that the influencerproduct degree of fit has an influence on online purchase intention [6,7]. Therefore, the hypothesis can be stated as follows:

H3a: The influencer-product degree of fit has a positive effect on online purchase intention.

One key to success in building effective marketing conversions is to build a proper alignment between influencers with the products it markets [6]. The influencer-product degree of fit has an influence on the attitude toward the ad [7]. Different studies also found that the influencer-product degree of fit has an influence on the attitude toward the ad [19]. Therefore, the following hypothesis is formed:

$\mathrm{H} 3 \mathrm{~b}$ : The influencer-product degree of fit has a positive effect on the attitude towards the ad.

Consumers generally have a positive attitude towards certain products or brands because consumers believe that the product has a level that is considered as a level of positive attributes [20]. The level of suitability of the product influencer has an influence on attitudes towards the brand [7]. In other studies, also found that the level of influencer-product fit has an influence on attitudes towards the brand [21]. Therefore, the hypothesis can be stated as follows:

H3c: Influencer-product degree of fit has a positive effect on the attitude towards the brand.

Placement of messages in advertising is one of the things that affect consumer judgments and decisions of a product [21]. The variable meaning transfer had an influence on online purchase intention [22,23]. Another research also found that the meaning of transfer has an influence on online purchase intention [6]. Therefore, the hypothesis can be stated as follows:

H4a: The influence of meaning transfer has a positive effect on online purchase intention.

The meaning transfer can be interpreted as meaning that moves into an ad and link to a widely accepted symbol. In the context of an influencer, a meaning to move from influencer through advertising. Meaning transfer variables have an influence on the attitude toward the ad [23]. Therefore, the hypothesis can be stated as follows:

H4b: Meaning the transfer has a positive effect on the attitude towards the ad.

Influencers can transfer a set of meanings that are relevant to consumers through brand/product through endorsements [24]. Information presented by trusted sources can influence consumers' beliefs, opinions, and attitudes [25]. Transfer of meaning has an influence on consumer attitudes on brands [23]. Hypotheses that can be proposed are:

$\mathrm{H} 4 \mathrm{c}$ : meaning the transfer has a positive effect on consumer attitudes towards brands

The feelings and cognitions related to consumer advertising are a significant driver of attitude toward the ad, which in turn gives a great influence on brand-related cognition, attitude toward the brand and purchase interest [16]. When consumers are exposed to ads, the effect can be observed through the reaction of consumers to provide a review of the brand to others, and how consumer behavior itself against product [26]. Attitude toward the ad has an influence on attitude toward the brand [7]. The hypothesis can be proposed as follows:

H5: Consumer attitudes towards advertising have a positive effect on consumer attitudes on brands.

Advertising is an easy process to improve cognitive consumers, with attention and motivation processes. This will increase the positive attitude toward advertising and brand and increase consumer buying interest [27]. Consumer attitudes toward advertising have an influence on online purchase intentions [7]. Different studies conducted [2] support the results of previous studies that attitudes towards advertising have an influence on online purchase intentions [2]. The hypothesis can be formulated as follows: 
H6: Consumer attitudes towards advertising have a positive effect on online purchase intentions.

Consumer attitudes toward the brand can be interpreted as conveying what is expected by the consumer in order to meet their needs. Therefore, consumer attitudes can stimulate the desire or interest to buy a product [28]. Consumer attitudes toward brands have an influence on consumer intentions to make purchases online [7]. Another study by Sallam and Algammash [26] obtained the same results which stated that consumers' attitudes towards brands influence consumer's intention to make online purchases [26]. Therefore, a hypothesis can be proposed:

H7: Consumer attitudes towards brands have a positive effect on online purchase intentions

\section{METHODS}

This research using hypothesis testing to answer parts of the problem statement. All the measurement items of the constructs were adapted from previous studies. A total of 265 respondents who have valid data and can be analyzed. The method used for data analysis is Structural Equation Modeling (SEM).

\section{RESULTS AND DISCUSSION}

\section{A. Results}

TABLE I. HYPOTHESIS RESULT

\begin{tabular}{|c|c|c|c|c|}
\hline Hypothesis & Coefficient & $\begin{array}{c}T- \\
\text { Statistic }\end{array}$ & P-Value & Conclusion \\
\hline $\begin{array}{l}\text { H1a: Influencer Credibility } \rightarrow \text { Online } \\
\text { Purchase Intention }\end{array}$ & -0.042 & 0.764 & 0.445 & $\begin{array}{l}\text { Not } \\
\text { Supported }\end{array}$ \\
\hline $\begin{array}{l}\text { H1b: Influencer Credibility } \rightarrow \text { Attitude } \\
\text { towards the Ad }\end{array}$ & 0.130 & 2,226 & 0,026 & Supported \\
\hline $\begin{array}{l}\text { H1c: Influencer Credibility } \rightarrow \text { Attitude } \\
\text { toward the Brand }\end{array}$ & 0.160 & 2,310 & 0,021 & Supported \\
\hline $\begin{array}{l}\text { H2a: Influencer Attractiveness } \rightarrow \\
\text { Online Purchase Intention }\end{array}$ & 0.092 & 1,256 & 0.210 & $\begin{array}{l}\text { Not } \\
\text { Supported }\end{array}$ \\
\hline $\begin{array}{l}\text { H2b: Influencer Attractiveness } \rightarrow \\
\text { Attitude towards the Ad }\end{array}$ & 0.267 & 2.866 & 0,004 & Supported \\
\hline $\begin{array}{l}\text { H2C: Influencer Attractiveness } \rightarrow \\
\text { Attitude towards the Brand }\end{array}$ & -0.016 & 0.208 & 0.835 & $\begin{array}{l}\text { Not } \\
\text { Supported }\end{array}$ \\
\hline $\begin{array}{l}\text { H3a: Influencer-Product Degree of Fit } \\
\rightarrow \text { Online Purchase Intention }\end{array}$ & -0.142 & 1,982 & 0,048 & $\begin{array}{l}\text { Not } \\
\text { Supported }\end{array}$ \\
\hline $\begin{array}{l}\text { H3b: Influencer-Product Degree of Fit } \\
\rightarrow \text { Attitude towards the Ad }\end{array}$ & 0.104 & 1.575 & 0.116 & $\begin{array}{l}\text { Not } \\
\text { Supported }\end{array}$ \\
\hline $\begin{array}{l}\text { H3c: Influencer-Product Degree of Fit } \\
\rightarrow \text { Attitude towards the Brand }\end{array}$ & 0,037 & 0.584 & 0.560 & $\begin{array}{l}\text { Not } \\
\text { Supported }\end{array}$ \\
\hline $\begin{array}{l}\text { H4a: Meaning Transfer } \rightarrow \text { Online } \\
\text { Purchase Intention }\end{array}$ & 0.099 & 1.249 & 0.212 & $\begin{array}{l}\text { Not } \\
\text { Supported }\end{array}$ \\
\hline $\begin{array}{l}\text { H4b: Meaning Transfer } \rightarrow \text { Attitude } \\
\text { towards the Ad }\end{array}$ & 0.304 & 3.386 & 0.001 & Supported \\
\hline $\begin{array}{l}\text { H4c: Meaning Transfer } \rightarrow \text { Attitude } \\
\text { towards the Brand }\end{array}$ & 0.129 & 1.755 & 0.080 & $\begin{array}{l}\text { Not } \\
\text { Supported }\end{array}$ \\
\hline $\begin{array}{l}\text { H5: Consumer Attitude towards Ad } \rightarrow \\
\text { consumer Attitude towards on Brands }\end{array}$ & 0.507 & 7.476 & 0.000 & Supported \\
\hline $\begin{array}{l}\text { H6: Consumer attitude towards } \mathrm{Ad} \rightarrow \\
\text { Online Purchase Intention }\end{array}$ & 0.215 & 2.241 & 0.025 & Supported \\
\hline $\begin{array}{l}\text { H7: Consumer Attitude towards the } \\
\text { Brand } \rightarrow \text { Online Purchase Intention }\end{array}$ & 0.445 & 4.160 & 0.000 & Supported \\
\hline
\end{tabular}

Table 1 shows that influencer's credibility has a significant positive effect on consumer attitudes towards advertising and also consumer attitudes toward brands (supporting H1b, H1c). The attractiveness of influencer has a significant positive effect on attitudes towards advertising (supporting $\mathrm{H} 2 \mathrm{~b}$ ). The meaning of transfer has a significant positive effect on consumer attitudes towards advertising (supporting H4b). Attitudes towards Advertising and attitudes towards brands have a significant positive effect on online purchase intentions (supporting H6, H7). The results also revealed that the effect of attitude towards the brand is greater than the attitude towards advertising on online purchase intentions

\section{B. Discussion}

The objectives of this study aims are to examine the influence of social media Influencer marketing on Attitude towards the Ad, Attitude towards the Brand and Online Purchase Intention. Social media influencers consisting of Influencer Credibility, Influencer Attractiveness, InfluencerProduct Degree of Fit and Meaning Transfer.

The results of hypothesis testing indicate the influencer's credibility does not influence the intention to make purchases online. The results of this study are consistent with research conducted by Lim et al. [6] but do not support previous research [7] which shows the influence of influencer's credibility on consumers' intention to make online purchases.

The credibility of an influencer can influence consumer attitudes towards advertising and also the brand. The results of this study support previous research conducted by researchers $[12,13]$.

Influencer attractiveness has a significant effect on online purchase intention. The results of this study are not by what was done by Sinaga and Kusumawati [14], which states that there is an influence between influencer attractiveness on online purchase intention. However, the results of this study support previous studies by Lim et al. [6] who stated that there was no significant influence between influencer attractiveness on online purchase intention.

The attractiveness of influencer has a significant effect on online purchase intentions. The results of this study are not following what was done by Sinaga and Kusumawati [14], however, supporting previous research by Lim et al. [6].

Influencer-product degree of fit has a positive and significant effect on online purchase intention. The results of this study are the following research conducted by Lim et al. [6]. The influencer-product degree of fit does not have a significant effect on attitude towards the ad and attitude towards the brand. The results of this study differ from studies conducted by Choi and Rifon [19] where the influencerproduct degree of fit influences attitude towards the ad. The results also differ from the results of research conducted by Wijaya [21] where there is an influence between the influencerproduct degree of fit on attitude towards the brand. 
The meaning of transfer has no significant effect on online purchase intention. The results of this study differ from research conducted by Roy and Jain, Miller and Allen [22,23] where there is an influence between meaning transfer to online purchase intention.

The meaning of transfer has a significant effect on attitudes towards advertising but does not affect attitudes towards brands. The results of this study are consistent with research conducted by Roy and Jain [22]. Related to attitudes towards brands the results of this study differ from the results of research conducted by Miller and Allen [23] where there is an influence between the meaning of the transfer on attitudes towards the brand.

Attitude towards the ad has a positive and significant effect on attitude towards the brand. The results of this study are consistent with research conducted by Gaied et al. [7].

Based on the results of hypothesis testing, it is known that Online Purchase Intention is directly affected by Attitude towards the Brand and Attitude towards Advertising. The results of this study are consistent with research conducted by Mukherjee and Banerjee [2] and also Salam and Algammash [26].

\section{CONCLUSION}

Based on the conclusion, the research can be used as a reference for business people who want to use influencer marketing services on social media.

Businesses should pay attention to the factors that make consumers interested in the product being marketed. Choosing the appropriate influencers with the product to be marketed into consideration is very important because it can influence the influencers of consumer buying interest towards the product. Besides, businesses need to choose influencers with good credibility, popularity, and influencers who have the information up to date, because influencer can influence consumer attitudes toward advertising market. Furthermore, influencers must also provide information correspond to reality and do their duties with full responsibility and have the experience of a marketed product, so that consumers will feel attracted to the brand when the brand is marketed by influencers. Although the credibility influencer only affects consumer attitudes toward the brand, it is expected the presence of the positive attitude of consumers will lead to an interest in buying the products. But through credibility will create consumer awareness of the product being marketed. For further research, it is advisable to choose a figure influencer that will be used as a role model in the study. Besides, further research is recommended to seek other social media who want to study, such as YouTube, Facebook, Twitter and so on.

\section{REFERENCES}

[1] D. Belanche I. Cenjor, and A. Pérez-Rueda, "Instagram Stories versus Facebook Wall: an advertising effectiveness analysis," Spanish J Mark ESIC., vol. 23, no. 1, pp. 69-94, 2019.
[2] K. Mukherjee and N. Banerjee, "Social networking sites and customers' attitude towards advertisements," J Res Interact Mark, vol. 13, no. 4, pp. 477-91, 2019.

[3] L. Probstnerová, The effect of fear on purchase intentions. Universiteit van Amsterdam, 2018

[4] M. Sudha and K. Sheena, "Impact of influencers in consumer decision process: The fashion industry," SCMS J Indian Manag., pp. 14-31, 2017.

[5] N. Zietek, Influencer marketing: The characteristics and components of fashion influencer marketing. The Swedish School of Textiles, University of Boras, 2016.

[6] X.J. Lim, A.M. Radzol, J. Cheah, and M.W. Wong, "The impact of social media influencers on purchase intention and the mediation effect of customer attitude," Asian Journal of Business Research, vol. 7, no. 2, pp. 19-36, 2017.

[7] A.M. Gaied and K.S.B. Rached, "The congruence effect between celebrity and the endorsed product in advertising," J Mark Manag, vol. 5, no. 1, pp. 2333-6099, 2017.

[8] S. Tanjung and H. Hudrasyah, "The impact of celebrity and noncelebrity endorser credibility in the advertisement on attitude towards advertisement, attitude towards brand, and purchase intention," In: International Conference on Ethics of Business, Economics, and Social Science, pp. 231-45, 2016.

[9] S. Gage, "Influencer Marketing Di Indonesia," [Online]. Retrieved from https://starngage.com/influencer-marketing-di-indonesia/

[10] W. Vollenbroek, S.De. Vries, E. Constantinides, and P. Kommers, "Identification of influence in social media communities," Int J Web Based Communities, vol. 10, no. 3, pp. 280-97, 2014.

[11] B. Sartika and I. Sukirno, "Pengaruh kredibilitas endorser Agnes Monica dalam iklan kartu prabayar Simpati di Televisi terhadap minal beli konsumen," Modus, vol. 26, no. 2, pp. 145-56, 2014.

[12] H.R. Gaber, L.T. Wright, and K. Kooli, "Consumer attitudes towards Instagram advertisements in Egypt: The role of the perceived advertising value and personalization," Cogent Bus Manag, vol. 6, no. 1, pp. 1-13, 2019.

[13] M.A.A. Sallam and N.A. Wahid, "Endorser Credibility Effects on Yemeni Male Consumer's Attitudes towards Advertising, Brand Attitude and Purchase Intention: The Mediating Role of Attitude toward Brand," Int Bus Res., vol. 5, no. 4, pp. 55-66, 2012.

[14] R.E.M. Sinaga and A. Kusumawati, "Pengaruh YouTube beauty vlogger terhadap minat beli konsumen dan dampaknya terhadap keputusan pembelian produk (Studi pada pengguna kosmetik Maybelline di Indonesia),"J Adm Bisnis, vol. 63, no. 1, pp. 187-96, 2018.

[15] D.D. Yusda, Pengaruh atribut credibility dan attractiveness celebrity endorser terhadap keputusan pembelian produk Sunsilk Clean \& Fresh pada konsumen wanita di Bandar Lampung. Universitas Lampung, 2016.

[16] C. Yilmaz, E.E. Telci, M. Bodur, and T.E. Iscioglu, "Source characteristics and advertising effectiveness: The roles of message processing motivation and product category knowledge," Int J Advert., vol. 30, no. 5, pp. 889-914, 2011.

[17] D.V.C. Saragih, E. Pangestuti, and L.D.R. Devita, "Pengaruh perceived value, celebrity endorser dan advertising terhadap brand attitude (Survei pada Mahasiswi Universitas Brawijaya pengguna kosmetik Wardah)," Adm Bisnis, vol. 64, no. 1, pp. 1-9, 2018.

[18] D.O.N. Rachmat, M. Ariyanti, and D.A. Zuliestiana, "Influence of instagram celebrity endorsement on consumer buying intention for hijab products," In: e-Proceeding of Management, pp. 2858-65, 2016.

[19] S.M. Choi and N.J. Rifon, "It is a match: The impact of congruence between celebrity image and consumer ideal self on endorsement effectiveness," Psychol Mark, vol. 29, no. 9, pp. 639-50, 2012.

[20] A.M. Susila, Pengaruh kredibilitas celebrity endorser terhadap sikap konsumen pada merek Esia (Studi pada artis Ringgo Agus Rahman). Universitas Indonesia, 2008. 
[21] P. Wijaya, "Pengaruh pesan iklan, keterlibatan iklan, kredibilitas, dan kecocokan endorser pada minat beli melalui sikap konsumen," J Siasat Bisnis, vol. 19, no. 1, pp. 36-55, 2015.

[22] S. Roy and V. Jain, "Exploring meaning transfer in celebrity endorsements: Measurement and validation," Asia-Pacific J Bus Adm., vol. 9, no. 2, pp. 87-104, 2017.

[23] F.M. Miller and C.T. Allen, "How does celebrity meaning transfer? Investigating the process of meaning transfer with celebrity affiliates and mature brands," J Consum Psychol, vol. 22, no. 3, pp. 443-52, 2012.

[24] A.L. Santos, F. Barros, and A. Azevedo, "Matching-up celebrities' brands with products and social causes," J Prod Brand Manag, vol. 28, no. 2, pp. 242-55, 2019.

[25] S.W. Wang, G.H.Y. Kao, and W. Ngamsiriudom, "Consumers' attitude of endorser credibility, brand and intention with respect to celebrity endorsement of the airline sector," J Air Transp Manag, vol. 60, pp. 107, 2017.

[26] M.A Sallam and F.A. Algammash, "The effect of Attitude toward Advertisement on attitude toward brand and purchase intention," Int J Econ Commer Manag United Kingdom, vol. 4, no. 2, pp. 21-9, 2016.

[27] M. Storme, N. Myszkowski, A. Davila, and F. Bournois, "How subjective processing fluency predicts attitudes toward visual advertisements and purchase intention," J Consum Mark, vol. 32, no. 6, pp. 432-40, 2015.

[28] D. Darmawan, R. Mardikaningsih, and M. Hariani, "The effects of endorser credibility, attitude toward to ADS, and brand attitude on purchase intention,” Relasi J Ekon, vol. 15, no. 2, pp. 263-76, 2019. 